\title{
JAROSLAVA VYDROVÁ:
}

\section{Výraz, dielo, telesnost'. Fenomenologické eseje}

\author{
Červený Kostelec: Pavel Mervart, 2019, 167 s.
}

Čo sa s nami deje, ked' sa hráme, ked' sa smejeme, ked' oddychujeme, ked' pracujeme? Kniha Výraz, dielo, telesnost' sa v šiestich esejach pokúša osvetlit' aj tieto otázky. Vydrová v knihe vychádza najmä z filozofických koncepcií zakladatel’a fenomenológie Edmunda Husserla a priekopníka filozofickej antropológie Helmuta Plessnera. Ciel'om knihy je za pomoci týchto filozofických východísk vrhnút' nové svetlo na niektoré aspekty skúsenosti človeka v modernej spoločnosti a zároveň v tomto kontexte preskúmat' vzt'ah súčasnej filozofie a moderného umenia. Kniha pozostáva $z$ úvodu a šiestich kapitol, pričom prvé štyri ${ }^{1}$ sa venujú okrem iného aj vzt’ahu filozofie a moderného umenia. Kubistická mal'ba, funkcionalistická architektúra, ${ }^{2}$ charakterové hlavy Franza Xavera Messerschmidta či Kunderov román Nesmrtelnost sú $\mathrm{v}$ týchto kapitolách konkrétnymi odrazovými mostíkmi $\mathrm{k}$ filozofickému uvažovaniu o vnímaní, bývaní a o vplyve prostredia na myslenie, o emóciách a sociálnych rolách, respektíve sociálnych hrách. Výber konkrétnych diel „podlieha [Vydrovej] osobnej preferencii a vychádza v prvom rade z [jej] vlastnej skúsenosti vnímania umeleckého diela“ (s. 9). ${ }^{3} \mathrm{~V}$ týchto kapitolách uvažuje nielen o pôsobení týchto diel, ale aj o tom, z akej kultúrnej situácie takéto diela vzišli, respektíve mohli vzíst', a ako sa táto situácia vzt'ahuje k našej súčasnej situácii. Piata kapitola Ked' oddychujeme sa venuje téme oddychu, únavy, športu a práce. Šiesta kapitola Nová otázka je zhrnujúca a venuje sa aktuálnosti Husserlovho a Plessnerovho myslenia v súčasnosti.

Ide o druhú autorskú monografiu Jaroslavy Vydrovej. Prvá vyšla v roku 2010 pod názvom Cesty fenomenológie a Vydrová sa v nej venovala Husserlovej metóde

\footnotetext{
${ }^{11}$ Kubizmus, oko a vec, V priestore a v prostredí, Zvláštny prípad: Messerschmidtove hlavy a Tvár, maska, nimbus.

${ }^{2}$ Vydrová odkazuje napríklad na tvorbu nemeckej architektky Lucy Hillebrandovej, v roku 1928 najmladšej členky Deutscher Werkbund, ktorá navrhovala aj Plessnerov dom.

${ }^{3}$ Pripomína to gesto, v ktorom Merleau-Ponty uviedol prvé vydanie svojej poslednej práce, L'Eil et l'Esprit, reprodukciami diel Giacomettiho, Matissa, Cézanna, de Staëla, Kleeho, Richiera a Rodina.
} 
fenomenologickej redukcie. Jedným z kl'účových záverov skoršej práce je, že fenomenologická metóda nie je neutrálnym, lubovol'ne aplikovatel'ným teoretickým nástrojom, ale ide o špecifický spôsob myslenia a pýtania, ktorý sám generuje špecifické témy a v konečnom dôsledku mení spôsob, akým sa orientujeme a pohybujeme vo svete. Podstatnou súčast'ou fenomenologickej metódy je teda aj následné vystúpenie z fenomenologicky redukovaného sveta: „V úzkej spojitosti s výkonom redukcie (a tým aj so skúsenost’ou) je návrat (Rückgang) do prirodzeného sveta, ktorý predstavuje druhý vel'ký kontext, v ktorom nachádzame formulovanie zmyslu“ (Vydrová 2010, 115).

Vydrovej nová kniha sa dá chápat' aj ako výkon takéhoto návratu. Témou tu už nie je epoché a podobne a fenomenologicky získané štruktúry pôsobia skôr akoby v pozadí. Plessnerova filozofia je interpretovaná ako kompatibilná s Husserlovou fenomenológiou, teda Vydrová predstavuje Plessnera ako filozofa, ktorý skúmal spoločnost' a kultúru, vychádzajúc z pozície samého kultúrne a sociálne angažovaného jednotlivca. Táto kombinácia umožňuje Vydrovej ostrejšie sa zamerat' na problematiku kultúry a spoločnosti, ktorá býva v Husserlových textoch väššinou len naznačená.

V žiadnej z konkrétnych prípadových štúdií následne nejde o „,aplikáciu“ fenomenologickej metódy na jednotlivé fenomény, uvažovanie nad fenomenológiou skôr v určitom obojsmernom pohybe vyjasňuje napríklad problematiku kubistickej mal'by a naopak. V prípade kubizmu Vydrová totiž súhlasí s Hansom Rainerom Seppom, podla ktorého „fenomenológia so svojou metódou pôsobí ako cezúra a v podobnom duchu sa aj v kubizme prejavuje jeho metóda. (...) Fenomenologická reflexia odhal'ujúca podmienky nazerania a mienenia tak má svoj analogon v kubistickom sledovaní ,syntaxe a sémantiky čistého zobrazovania“" (s. 38 - 39). Fenomenológia aj kubizmus akoby kládli podobnú otázku: ako sa nám predmety vnímania vôbec môžu dávat' ako zmysluplné, nielen ako nesúvislý príval vnemových dát? A obe akoby pri analýze postupovali podobnou cestou redukcie, pričom nechávajú predmety vnímania samé vyvstávat' zo základných stavebných kameňov perceptívnej skúsenosti.

Vzájomné inšpirácie nachádza aj v prípade Messerschmidtových hláv. Ide o sochárske štúdie emócií, ktoré zachytávajú rôznym spôsobom napäté tváre. Kontext dodávajú len názvy búst (Zadržaný smiech, Zívajúci a pod.), ak sa však sústredíme len na samotné tváre, ide o zamrznuté, paradoxné výrazy, pri ktorých očakávame, že sa nejakým smerom rozvinú a uvol'nia, no konkrétny smer tohto uvol'nenia ešte nie je daný: „Cítime, že Messerschmidtom zachytený výraz je svojím spôsobom neúnosný, bezbrehý a nemôže ostat' trvalejším prejavom subjektivity“ (s. 87). Vydrová v týchto 
„kŕčoch“ pozoruje paralely s fenomenologickým konceptom „,hraničnosti“. „Výrazová štruktúra emocionálneho preživania $\mathrm{v}$ skutočnosti odhaluje človeka $\mathrm{v}$ jeho bytostnej podobe, ktorú predstavuje jeho hraničnost'. Smiechu prepadáme, pri plači sa mu vzdávame a dezorganizácia telesnej a duševnej stránky tu pôsobí ako akt, ktorý nás presahuje“ (s. 75). Fenomenológia, ktorá tu zvnútra naráža na hranice danosti a napína do extrému svoje schopnosti deskripcie, tak môže v určitej fáze odovzdat' vysvetl'ovanie míkvemu sochárskemu umeniu.

Vel'mi podnetná je piata esej, venovaná vol'nému času. Oddych a práca sa ukazujú ako určité reverzibilné figúry, kde oddych sa z pozície práce javí ako lenivost' a práca sa z pozície oddychu javí ako zdroj únavy. Následne napríklad rekreačný šport umožňuje, aby sa oddych nejavil ako lenivost', ale ako zmysluplná aktivita, $\mathrm{v}$ ktorej sa dosahujú ciele a saturuje sa pocit úspechu v rámci jednoznačne vymedzeného súperenia, ktoré $\mathrm{v}$ práci často absentuje - najmä pri jej abstraktnej del'be $v$ kapitalistickej spoločnosti. Šport sám sa však môže stat' niečím, čoho jediným zmyslom sa stane dosahovanie výkonov - a vtedy sa v podstate stáva opät' niečím ako prácou. Vydrová uzatvára danú esej tézou, že je potrebné obnovit’ „kultickost““ vol'ného času (s. 126). V tomto smere by bolo možné rozvíjat' úvahy napríklad smerom k Veblenovej Teórii záhal'čivej triedy (1999). Vydrová by zrejme predmet Veblenovho skúmania označila ako „úpadkovú formu“ trávenia vol'ného času, no Veblen zároveň ukazuje, aké nesmierne náročné je trávit' vol'ný čas rituálne; inak povedané, aké namáhavé je ostentatívne, viditel'ne nič nerobit'. Zaujímavé by mohlo byt' aj komparatívne zhodnotenie Adornovej $(1991,189)$ radikálnej kritiky samého konceptu vol'ného času ako prejavu „dnes rozšírenej barbarskej mentality“.

Jednotlivé eseje sú podnetné, no kniha má podl'a mňa aj širší význam, ak sa pýtame na súčasnú relevantnost' fenomenologickej filozofie. Fenomenológia býva chápaná ako jedna z posledných modernistických filozofických snáh podat' ucelený výklad sveta tým, že vyjasní podstatné základy skúsenosti a poznania. Zároveň vždy čelila kritike, že tento pokus nebol, a ani nikdy nemohol byt' úspešný. Foucault (1987, 343) tvrdí, že fenomenológia vo svojom praktickom výkone, ked' sa sústredí na partikulárne skúsenosti a prežívanie, robí potichu „ústupky antropológii“, ktorá spracováva empirické obsahy, no na rozdiel od fenomenológie im nepotrebuje nevyhnutne dodávat' transcendentálny význam.

Vydrová nerobí antropológii „tiché ústupky“, ale aktívne ju zapája do tej miery, že fenomenológia sa javí čiastočne ako antropológia a naopak. Pri Husserlovi tu nachádzame referencie $\mathrm{k}$ tradičným fenomenologickým témam: intencionalita, intersubjektivita, telesnost' na osi Körper - Leib atd'. Viac ako systematik však tentoraz Husserl vystupuje ako bádatel', sondujúci každodenné skúsenosti bez toho, aby ich nevy- 
hnutne systematizoval; v dvoch kapitolách napríklad Vydrová nachádza plodné inšpirácie v Husserlovej okrajovej meditácii o tabaku a fajčení. Takáto fenomenologická antropológia sa $\mathrm{v}$ podstate javí ako vytrénovanejšia reflexia.

Nemyslím si však, že takéto skúmanie je bez transcendentálneho významu. Záverečné úvahy v knihe sú metodologické: aký je význam takto postupujúcej filozofie? Podl'a Vydrovej ,filozofia, ktorá reflektuje celé toto pole l'udského bytia, nie je l'ubovol'nou hrou alebo hádankou, ale nie je ani otázkou s predznačenou štruktúrou odpovede“ (s. 140). Nakol'ko predchádzajúce eseje sú zjavne preniknuté fenomenologickým terminologickým aparátom, ktorý odpovede predbežne štruktúruje, toto tvrdenie nie je tak celkom presvedčivé. To však nevadí; práve naopak. Keby sa fenomenológia vzdala úsilia o transcendentálne ukotvenie, ako by potom odpovedala napríklad na Latourovu $(2005,244)$ kritiku, že sa zbytočne obmedzuje na bezprostredné vzt'ahy vzt’ahy takpovediac „tvárou v tvár“ - vychádzajúce z filozofovho centra? Nie sú azda bohatšie deskripcie, ktoré možno začat' v l'ubovol'nom bode, nie len vo filozofovej prežitej skúsenosti? Fenomenológia totiž vždy v konečnom dôsledku hovorí o sebe; fenomenológ napokon vždy reflektuje na svoju pozíciu filozofa vo svete. Vo fenomenológii sa však očakáva, že toto obmedzenie je kompenzované práve jej transcendentálnymi ambíciami, ktoré tkvejú v možnosti podat' systematický výklad, čo zahŕňa aj schopnost' štruktúrovat' odpovede v budúcnosti.

Podl'a Latoura $(2005,258$ - 262) tu napokon ide aj o otázku politiky. Zmnožovanie deskripcií má politický význam v tom, že, jednoducho povedané, jednotliví aktéri v sociálnych vzt’ahoch budú lepšie rozumiet' sami sebe, druhým a tomu, ako medzi nimi vzniká „socialita“. A toto postupné porozumenie, ktoré prináša vyjasňovanie, je zároveň podl'a Latoura $(2003,70)$ jediné, čo môžeme robit’ - revolúcia nie je možná. Fenomenológia má z jednej strany vel'mi podobnú ambíciu - čiastkovo vyjasňovat' fenomény, aby sme si lepšie rozumeli. Vydrovej kniha je príkladom presne takéhoto fenomenologického bádania; analýzy kubizmu, Messerschmidta či vol’ného času rozhodne nie sú určené len akademickým filozofom. Avšak fenomenológ zároveň verí, že nie sme odkázaní len na zmnožovanie deskripcií, no aspoň implicitne pripúšt’a možnost' systematizácie a následne možnost' premeny celkového spôsobu videnia a chápania sveta. Je tu teda zároveň príslub radikálneho a rozsiahleho vyjasnenia.

Eseje v tejto knihe sú teda cenné nielen pre podnetnost' partikulárnych analýz, ale aj tým, že Vydrová perfektne ovláda „čistú fenomenológiu“, ktorá im dodáva filozofické podložie. Husserl $(1998,354)$ v roku 1935 povedal: „Ja, údajný reakcionár, som omnoho radikálnejší a d’aleko revolučnejší než tí, ktorých radikalizmus sa dnes prejavuje len slovami." Vydrová sa v knihe prikláňa $\mathrm{k}$ Plessnerovej kritike radikalizmu, ktorý podl’a neho „vie mysliet’ len v pojmoch základných kategórii““ (s. 60). 
Zároveň však vo svojich esejach ponecháva v hre základné kategórie, získané vo fenomenologickej tradícii, a hladá myslenie, ktoré sa o ne dokáže opriet' a využit' ich aj do budúcnosti, avšak bez toho, aby prebiehalo výlučne v týchto pojmoch. Medzi kritikou, ktorá za každým fenoménom vidí prácu rozsiahlych rigidných štruktúr, a čistou deskripciou, ktorá sa vyhýba akýmkol'vek zovšeobecneniam, má takáto filozofia predsa len $\mathrm{v}$ istom zmysle radikálny potenciál.

Michal Lipták

\section{Literatúra}

ADORNO, T. W. (1991): The Culture Industry. London / New York: Routledge.

FOUCAULT, M. (1987): Slová a veci. Bratislava: Pravda.

HUSSERL, E. (1998): Krize evropských věd a transcendentálni fenomenologie. Praha: Academia.

LATOUR, B. (2003): Nikdy sme neboli moderní. Bratislava: Kalligram.

LATOUR, B. (2005): Reassembling the Social. Oxford: Oxford University Press.

VEBLEN, T. (1999): Teorie záhalčivé třidy. Praha: SLON.

VYDROVÁ, J. (2010): Cesty fenomenológie. Fenomenologická metóda neskorého Husserla. Pusté Úl'any: Schola Philosophica.

Michal Lipták

Filozofický ústav SAV

Klemensova 19

81364 Bratislava

e-mail: iammichal@gmail.com

ORCID ID: https://orcid.org/0000-0002-4333-6108 